\title{
A CROSS-SECTIONAL SURVEY OF THE PREVALENCE AND THE RISK FACTORS OF TOBACCO USE AMONGST CONSTRUCTION ARTISANS IN EKITI STATE, NIGERIA
}

Charles Oluwatemitope Olomofe ${ }^{1,2}$, Caryl M Benyon ${ }^{1}$, Kabir Adekunle Durowade ${ }^{2}$, Oluwafunmike Ruth Olomofe ${ }^{3}$.

${ }^{1}$ Department of Health and Policy, University of Liverpool, Liverpool, United Kingdom

${ }^{2}$ Department of Community Medicine, Federal Teaching Hospital, Ido-Ekiti, Ekiti State, Nigeria

${ }^{3}$ Department of International Law, Federal Ministry of Justice, Maitama, Abuja, Nigeria

\begin{abstract}
Background: Construction artisans are those who perform skilled work relating to the erection or assembly of a large structure. These artisans are prone to tobacco use. This study aims to assess the prevalence and the associated risk factors of tobacco use amongst construction artisans in Ekiti State, Nigeria.
\end{abstract}

Materials and Methods: This cross-sectional study employed a multi-stage sampling technique to select participants (carpenters and bricklayers) artisans, journeymen, and their apprentices who were working in Ekiti State. Chi-square and logistic regression were used to test for association in bivariate and multivariate analyses respectively.

Results: The prevalence of ever-smoke amongst respondents was 19.3\%. Multivariate analysis showed that artisans who were within the age range 31-40 years were four times 
medRxiv preprint doi: https://doi.org/10.1101/2021.04.08.21255137; this version posted April 11, 2021. The copyright holder for this preprint

more likely to use tobacco $(\mathrm{OR}=3.410 ; \mathrm{CI}=1.476-7.878)$. Similarly, being in school and divorced/separated were associated with tobacco use.

Conclusion: Noting the increased prevalence of tobacco use among construction artisans when compared to the general population, and few self-reported cases of addiction amongst users demands action from communities and government at all levels.

\section{Keywords}

Construction artisans, tobacco use, Nigeria

\section{BACKGROUND}

The construction industry plays a major and significant role in the employment creation and economic growth of many nations. As high as eighty percent of people work in the informal sector (not employed by the government) in Nigeria. ${ }^{1}$ and construction workers constitute a major chunk of this population. ${ }^{1}$ The construction industry in Nigeria also contributes significantly to the gross domestic product of the country. ${ }^{1,2}$ Construction artisans (CA) are those who perform skilled work relating to the erection or assembly of large structures such as buildings, roads, and bridges with their hands. ${ }^{3,4}$ The CA is equipped mainly with vocational education; this may be acquired formally or informally through observation, apprenticeship, and short learning cycle. ${ }^{5}$ Occupations such as carpenters, plumbers, electricians, welders, bricklayers, and painters are included in this category. ${ }^{4}$

Tobacco smoking is the leading cause of preventable morbidity and mortality worldwide. Every day over 13000 people worldwide die from tobacco and nearly 6 million people succumb to tobacco-related illnesses annually. ${ }^{6}$ More so, assuming current patterns of tobacco use and intervention efforts, WHO projects that from 2000 to 2030 the number of smokers will rise from 1.2 billion to 1.6 billion and the annual number of deaths will increase from 4.9 million to 10 million. ${ }^{6}$ Moreover, about 600,000 non-smokers die yearly because of 
medRxiv preprint doi: https://doi.org/10.1101/2021.04.08.21255137; this version posted April 11, 2021. The copyright holder for this preprint

being exposed to secondhand smoke. Research shows that nearly $80 \%$ of the world's 1 billion smokers live in low and middle-income countries (LMICs). ${ }^{6}$ The increasing burden of noncommunicable diseases in developing countries with tobacco use being implicated as a risk factor in a number of these diseases is a clear call to make tobacco control a central theme. ${ }^{7}$ Sustainable Development Goal 3 (SDG 3) underscores this by setting a target to strengthen the implementation of the World Health Organization Framework Convention on Tobacco Control (WHOFCTC) in all countries by the year $2030 .^{8}$

The prevalence of smoking amongst CA in Nigeria is $9.6 \%{ }^{3}$ and it is greater than $3.9 \%$ which is the prevalence of smoking in the general Nigerian population. ${ }^{9} \mathrm{CA}$ such as carpenters, plumbers, tillers has higher rates of smoking than workers in other occupations. ${ }^{10}$ In the United States, compared to all other occupational groups, construction workers had the highest number of ever-smokers (48\% compared to $39 \%$ for all other occupations combined). ${ }^{11}$

This group of artisans works under stressful conditions, and this makes them prone to some behavioral manifestations. ${ }^{3}$ Coupled with their stressful work environment, CA also belongs to the lower socio-economic cadre in Nigeria, people who lack access to information and social amenities. ${ }^{12}$ These socio-demographic and socio-economic inequalities, on the one hand, make CA indulge in the use of tobacco, and on the other hand make them unable to appreciate the health implications of doing so. ${ }^{12}$

According to the health belief model, the perceived susceptibility to illness and personal benefits are critical factors in health-related behavior. ${ }^{13}$ In this light, most CA is not aware of the consequences of smoking and they do not think they are vulnerable to, say, lung cancer. This low perception of illness coupled with the 'enjoyment' and increased work speed (benefits) these workers derived from smoking $^{3}$ makes them persist in this unhealthy 
behavior. Ajzen and Fishbein's proposition (1980) in the theory of reasoned action also governs the tendency of artisans to indulge in this risky behavior. ${ }^{13}$

There is a paucity of data on the status and wellbeing of the artisan in Nigeria, but as the global economy continues to shrink and unemployment remains high, artisanship may provide a major source of livelihood to the teeming population of unemployed youths. It is therefore imperative to make the overall health status of these workers a priority. This study attempted to determine the prevalence of tobacco use amongst CA and identified the factors responsible for this burden in Ekiti State, Nigeria.

\section{METHODS}

The study was carried out in Ekiti State, which is one of the thirty-six states of Nigeria. It is in the south-western part of the country. The State has 16 Local Government Areas (LGAs), and three senatorial districts. Ekiti State is a culturally homogenous state, inhabited predominantly by the Ekiti sub-ethnic group of the Yorubas. The study population consisted of CA, journeymen, and their apprentices who were carpenters and bricklayers. Research approval was obtained from the University of Liverpool ethics committee and the Ethics and Research Review Committee of the Federal Teaching Hospital, Ido Ekiti, Ekiti State, Nigeria.

The study was conducted using a pre-tested, semi-structured questionnaire and included CA, journeyman, or their apprentice who were above the age of 18 years and consented to participate in the study. The minimum sample size was determined to be 232 at a confidence level of $95 \%$ based on the proportion of tobacco use amongst artisans in a previous study $9.6 \%$ in a previous study ${ }^{3}$ and a $5 \%$ margin of error. 
medRxiv preprint doi: https://doi.org/10.1101/2021.04.08.21255137; this version posted April 11, 2021. The copyright holder for this preprint

The questionnaire was adapted from the contents of validated World Health Organization/Centre for Disease and Control Global Adult Tobacco Survey (GATS) and the WHO MONICA project protocol for recording smoking history. ${ }^{9}$

It comprised of two sections; Socio-demographic characteristics of respondents and respondents are smoking history. The pre-test of the questionnaire was done on $10 \%$ of the subjects in Ido/Osi LGA which was not included in the study. The pretested questionnaires with participants' information sheets were administered directly to the artisans at their place of work by the researcher. The data was collected from November 2018 to January 2019.

Data collation and editing were conducted manually to detect omissions and to ensure uniform coding. The data was entered into a computer and analysis was completed using SPSS version 21. All categorical variables, frequency tables, and cross-tabulations were generated (Jekel et al., 2001). A chi-square test was used to determine the statistical significance and association between dependent and independent variables. A chi-square was preferred because both variables were categorical. ${ }^{14} \mathrm{~A}$ multivariate analysis using logistic regression was also carried out to determine the factors associated with smoking. A logistic regression analysis was preferred because every smoke is a dichotomous variable (Yes or No) and many independent variables can be tested for association in this analysis. ${ }^{14}$ The level of significance was predetermined at a p-value of less than 0.05 at a $95 \%$ confidence level.

\section{RESULTS}

A total of $236 \mathrm{CA}$ were approached in the chosen communities in Ekiti State, four (4) declined to participate citing work schedule and personal engagements as reasons. Among the 232 that responded, only 228 responded well (4 provided incomplete data) giving a $98.3 \%$ response rate. Most of the respondents were between the ages of 21-30 years. All respondents were males. Almost half (46.9\%) of the respondents had secondary education as their highest 
medRxiv preprint doi: https://doi.org/10.1101/2021.04.08.21255137; this version posted April 11, 2021. The copyright holder for this preprint

level of education, and only $21.1 \%$ had tertiary education. Almost three-fifths (57\%) of the respondents were married while the remaining $43 \%$ were either single (33.3\%), Divorced separated $(6.6 \%)$, or widowed $(3.1 \%)$. Two-fifths $(39.9 \%)$ of the respondents were apprentices but a third $(33.8 \%)$ of the respondents had more than 20 years of work experience. Over $60 \%$ of the respondents were adept in their work while about $40 \%$ were an apprentice. A third (33.8\%) of the CA had more than 20 years of experience at the job (Table 1).

Amongst the respondents, $19.3 \%$ had ever smoked a cigarette in the last 12 months while more than $80 \%$ of the CA had not. More than half $(53.2 \%)$ of ever smokers started smoking before the age of 20 years and two-thirds (65.9\%) of the CA admitted to having started the habit because of friends. Half $(50 \%)$ of the ever-smokers still indulge in the habit, and $90 \%$ of them continued in this habit for pleasure they derived from smoking (Table 2). Just 9.1\% of the current smokers indulge in the habit for recognition amongst peers. More than two-thirds (68.2\%) of the CA smokes between 1-5 cigarette sticks per day, and $31.8 \%$ smokes over 5 cigarette sticks per day. Only $31.8 \%$ of ever smokers amongst the CA believed that the nature of their job demands they smoke (Table 2). Furthermore, $86.4 \%$ admitted to the fact that the smoking habit of their colleagues enticed them to smoke cigarettes. All the respondents were aware that smoking is injurious to health and all had to access the health information on tobacco use. However, $90.9 \%$ of the CA who currently smokes were willing to quit but $9.1 \%$ did not want to quit smoking because feel they were addicted and could not imagine their life without a cigarette (Table 2).

There was a statistically significant association between age and tobacco use amongst CA $(\mathrm{p}<0.001)$ (Table 3). CA within the age range 31-40 and those $\leq 20$ years have more smokers than those in other age groups. Similarly, there was a statistically significant association $(\mathrm{p}=0.039)$ between smoking and being in school (Table 3). CA who were in school smoke 
more than those who were not in school. There was also a significant association between tobacco use and not being an apprentice $(\mathrm{p}<0.001)$. CA who were adept in their occupation smoke more than those who were an apprentice. In a similar vein, there was a statistically significant association between years of experience and tobacco use $(\mathrm{p}=0.044)$. CA with over 20 years of experience smoke more than those with fewer years of experience.

CA who are within the age range $31-40$ years is 3.4 times more likely to use tobacco than those $\leq 20$ years $(\mathrm{OR}=3.410 ; \mathrm{CI}=1.476-7.878)$ (Table 4). Similarly, those that are currently in school and those who are divorced/ separated are twice likely (OR 2.007; CI= 1.026-3.927) and 4.2 times more likely $(\mathrm{OR}=4.240 ; \mathrm{CI}=1.307-13.759)$ to use tobacco than those not in school and those single respectively. Furthermore, CA who were not apprentice were 4.4 times more likely to smoke than those who are apprentices $(\mathrm{OR}=4.440 ; \mathrm{CI}=1.882-10.475)$. Moreover, $\mathrm{CA}$ have 6-10 years $(\mathrm{OR}=4.000 ; \mathrm{CI}=1.109-14.432), 11-20$ years $(\mathrm{OR}=4.375$; $\mathrm{CI}=1.050-18.234)$, and $>20$ years $(\mathrm{OR}=5.250 ; \mathrm{CI}=1.693-16.278)$ of experience are four times, 4.3 times, and 5.2 times more likely to smoke than artisans with less than 1 year of experience respectively (Table 4). 
Table 1: Socio-demographic characteristics of respondent construction artisans

\begin{tabular}{|c|c|c|}
\hline Variable & $\begin{array}{r}\text { Frequency } \\
\mathbf{N}=\mathbf{2 2 8} \\
\end{array}$ & $\begin{array}{r}\text { Percentage } \\
(\%)\end{array}$ \\
\hline \multicolumn{3}{|l|}{ Age group (in years) } \\
\hline$\leq 20$ & 76 & 33.3 \\
\hline $21-30$ & 65 & 28.5 \\
\hline $31-40$ & 46 & 20.2 \\
\hline$>40$ & 41 & 18.0 \\
\hline Gender (Males) & 228 & 100 \\
\hline \multicolumn{3}{|l|}{ Currently in school } \\
\hline Yes & 103 & 45.2 \\
\hline No & 125 & 54.8 \\
\hline \multicolumn{3}{|c|}{ Highest educational level } \\
\hline None & 12 & 5.3 \\
\hline Primary & 32 & 14.0 \\
\hline Secondary & 107 & 46.9 \\
\hline Vocational & 29 & 12.7 \\
\hline Tertiary & 48 & 21.1 \\
\hline \multicolumn{3}{|l|}{ Marital status } \\
\hline Single & 76 & 33.3 \\
\hline Married & 130 & 57.0 \\
\hline Divorced/ Separated & 15 & 6.6 \\
\hline Widowed (er) & 7 & 3.1 \\
\hline \multicolumn{3}{|c|}{ Marriage type (if ever married) } \\
\hline Monogamous & 118 & 77.6 \\
\hline Polygamous & 34 & 22.4 \\
\hline \multicolumn{3}{|l|}{ Religion } \\
\hline Christianity & 181 & 79.4 \\
\hline Islam & 31 & 13.6 \\
\hline Traditional & 16 & 7.0 \\
\hline \multicolumn{3}{|l|}{ Tribe } \\
\hline Yoruba & 192 & 84.2 \\
\hline Hausa & 10 & 4.4 \\
\hline Igbo & 22 & 9.6 \\
\hline Others & 4 & 1.8 \\
\hline \multicolumn{3}{|l|}{ Apprentice } \\
\hline Yes & 91 & 39.9 \\
\hline No & 137 & 60.1 \\
\hline \multicolumn{3}{|l|}{ Years of experience } \\
\hline$<1$ & 60 & 26.3 \\
\hline $1-5$ & 34 & 14.9 \\
\hline $6-10$ & 36 & 15.8 \\
\hline $11-20$ & 21 & 9.2 \\
\hline$>20$ & 77 & 33.8 \\
\hline
\end{tabular}


Table 2: The smoking history of construction artisans in this study

\begin{tabular}{|c|c|c|}
\hline Variable & $\begin{array}{r}\text { Frequency } \\
\mathrm{N}=44\end{array}$ & $\begin{array}{r}\text { Percentage } \\
(\%)\end{array}$ \\
\hline \multicolumn{3}{|c|}{ Ever smoke a cigarette in the last 12 months } \\
\hline Yes & 44 & 19.3 \\
\hline No & 184 & 80.7 \\
\hline \multicolumn{3}{|l|}{ Total $=228$} \\
\hline \multicolumn{3}{|c|}{ Age at first smoke } \\
\hline$<20$ years & 23 & 52.3 \\
\hline$\geq 20$ years & 21 & 47.7 \\
\hline \multicolumn{3}{|c|}{ Reasons you started } \\
\hline Friends & 29 & 65.9 \\
\hline Adventure & 15 & 34.1 \\
\hline \multicolumn{3}{|c|}{ Currently, smoke } \\
\hline Yes & 22 & 50.0 \\
\hline No & 22 & 50.0 \\
\hline \multicolumn{3}{|c|}{ Reason for still indulging $(\mathrm{n}=\mathbf{2 2})$} \\
\hline Pleasure & 20 & 90.9 \\
\hline Recognition & 2 & 9.1 \\
\hline \multicolumn{3}{|c|}{ Average no of sticks per day $(n=22)$} \\
\hline $1-5$ & 15 & 68.2 \\
\hline$>5$ & 7 & 31.8 \\
\hline \multicolumn{3}{|c|}{ Nature of work demands to smoke } \\
\hline Yes & 14 & 31.8 \\
\hline No & 30 & 68.2 \\
\hline \multicolumn{3}{|c|}{ No of my co-workers smoking } \\
\hline$<5$ & 36 & 81.8 \\
\hline$\geq 5$ & 8 & 18.2 \\
\hline \multicolumn{3}{|c|}{ Aware smoking is injurious to your health } \\
\hline Yes & 42 & 95.5 \\
\hline No & 2 & 4.5 \\
\hline \multicolumn{3}{|c|}{ A co-worker's smoking habit entices you to smoke } \\
\hline Yes & 38 & 86.4 \\
\hline No & 6 & 13.6 \\
\hline \multicolumn{3}{|c|}{ Want to quit smoking $(\mathrm{n}=22)$} \\
\hline Yes & 20 & 90.9 \\
\hline No & 2 & 9.1 \\
\hline
\end{tabular}


Table 3: Socio-demographic factors associated with ever smokers among respondent construction artisans

\begin{tabular}{|c|c|c|c|c|c|}
\hline \multirow[t]{2}{*}{ Variable } & \multicolumn{2}{|c|}{ Ever use tobacco } & \multirow[b]{2}{*}{$\chi^{2}$} & \multirow[b]{2}{*}{ Df } & \multirow[b]{2}{*}{ p-value } \\
\hline & $\begin{array}{c}\text { Yes } \\
\mathbf{n}(\%)\end{array}$ & $\begin{array}{c}\text { No } \\
\text { n }(\%)\end{array}$ & & & \\
\hline \multicolumn{6}{|l|}{ Age group (in years) } \\
\hline$\leq 20$ & $13(17.1)$ & $63(82.9)$ & 18.903 & 3 & $1<0.00]$ \\
\hline $21-30$ & $7(10.8)$ & $58(89.2)$ & & & \\
\hline $31-40$ & $19(41.3)$ & $27(58.7)$ & & & \\
\hline$>40$ & $5(12.2)$ & $36(87.8)$ & & & \\
\hline \multicolumn{6}{|l|}{ Currently in school } \\
\hline Yes & $26(25.2)$ & $77(74.8)$ & 4.263 & 1 & 0.039 \\
\hline No & $18(14.4)$ & $107(85.6)$ & & & \\
\hline \multicolumn{6}{|c|}{ Highest educational level } \\
\hline None & $1(8.3)$ & $11(91.7)$ & 8.537 & 4 & 0.074 \\
\hline Primary & $1(3.1)$ & $31(96.9)$ & & & \\
\hline Secondary & $23(21.5)$ & $84(78.5)$ & & & \\
\hline Vocational & $6(20.7)$ & $23(79.3)$ & & & \\
\hline Tertiary & $13(27.1)$ & $35(72.9)$ & & & \\
\hline \multicolumn{6}{|l|}{ Marital status } \\
\hline Single & $13(17.1)$ & $63(82.9)$ & 8.306 & 3 & 0.040 \\
\hline Married & $22(16.9)$ & $108(83.1)$ & & & \\
\hline Divorced/ Separated & $7(46.7)$ & $8(53.3)$ & & & \\
\hline Widowed & $2(28.6)$ & $5(71.4)$ & & & \\
\hline \multicolumn{6}{|c|}{ Marriage type (if ever married) } \\
\hline Monogamous & $19(16.1)$ & $99(83.9)$ & 5.988 & 1 & 0.014 \\
\hline Polygamous & $12(35.3)$ & $22(64.7)$ & & & \\
\hline \multicolumn{6}{|l|}{ Religion } \\
\hline Christianity & $33(18.2)$ & $148(81.8)$ & 0.978 & 2 & 0.613 \\
\hline Islam & $8(25.8)$ & $23(74.2)$ & & & \\
\hline Traditional & $3(18.8)$ & $13(81.2)$ & & & \\
\hline \multicolumn{6}{|l|}{ Tribe } \\
\hline Yoruba & $35(18.2)$ & $157(81.8)$ & 1.126 & 3 & 0.771 \\
\hline Hausa & $2(20.0)$ & $8(80.0)$ & & & \\
\hline Igbo & $6(27.3)$ & $16(727)$ & & & \\
\hline Others & $1(25.0)$ & $3(75.0)$ & & & \\
\hline \multicolumn{6}{|l|}{ Apprentice } \\
\hline Yes & $7(7.7)$ & $84(92.3)$ & 13.098 & 1 & $<0.001$ \\
\hline No & $37(27.0)$ & $100(73.0)$ & & & \\
\hline \multicolumn{6}{|l|}{ Years of experience } \\
\hline$<1$ & $4(6.7)$ & $56(93.3)$ & 9.823 & 4 & 0.044 \\
\hline $1-5$ & $6(17.6)$ & $28(82.4)$ & & & \\
\hline $6-10$ & $8(22.2)$ & $28(77.8)$ & & & \\
\hline
\end{tabular}




\begin{tabular}{lrr}
\hline $11-20$ & $5(23.8)$ & $16(76.2)$ \\
$>20$ & $21(27.3)$ & $56(72.7)$ \\
\hline
\end{tabular}

Table 4: Adjusted Odd Ratios for the associated factors of ever smokers among respondents

\begin{tabular}{|c|c|c|c|c|}
\hline \multirow[t]{2}{*}{ Variable } & \multirow[t]{2}{*}{ AOR } & \multicolumn{2}{|c|}{ 95\% CI for AOR } & \multirow[b]{2}{*}{ p-value } \\
\hline & & Lower & Upper & \\
\hline \multicolumn{5}{|l|}{ Age group (in years) } \\
\hline$\leq 20$ & 1.000 & & & \\
\hline $21-30$ & 0.585 & 0.218 & 1.567 & 0.282 \\
\hline $31-40$ & 3.410 & 1.476 & 7.878 & 0.003 \\
\hline$>40$ & 0.673 & 0.222 & 2.042 & 0.482 \\
\hline \multicolumn{5}{|l|}{ Currently in school } \\
\hline Yes & 2.007 & 1.029 & 3.927 & 0.039 \\
\hline No & 1.000 & & & \\
\hline \multicolumn{5}{|l|}{ Marital status } \\
\hline Single & 1.000 & & & \\
\hline Married & 0.987 & 0.465 & 2.096 & 0.973 \\
\hline Divorced/ Separated & 4.240 & 1.307 & 13.759 & 0.012 \\
\hline Widowed & 1.939 & 0.339 & 11.101 & 0.451 \\
\hline \multicolumn{5}{|c|}{ Marriage type (if ever married) } \\
\hline Monogamous & 1.000 & & & \\
\hline Polygamous & 2.842 & 1.205 & 6.701 & 0.040 \\
\hline \multicolumn{5}{|l|}{ Apprentice } \\
\hline Yes & 1.000 & & & \\
\hline No & 4.440 & 1.882 & 10.475 & $<0.001$ \\
\hline \multicolumn{5}{|l|}{ Years of Experience } \\
\hline$<1$ & 1.000 & & & \\
\hline $1-5$ & 3.000 & 0.782 & 11.504 & 0.097 \\
\hline $6-10$ & 4.000 & 1.109 & 14.432 & 0.026 \\
\hline $11-20$ & 4.375 & 1.050 & 18.234 & 0.031 \\
\hline$>20$ & 5.250 & 1.693 & 16.278 & 0.002 \\
\hline
\end{tabular}




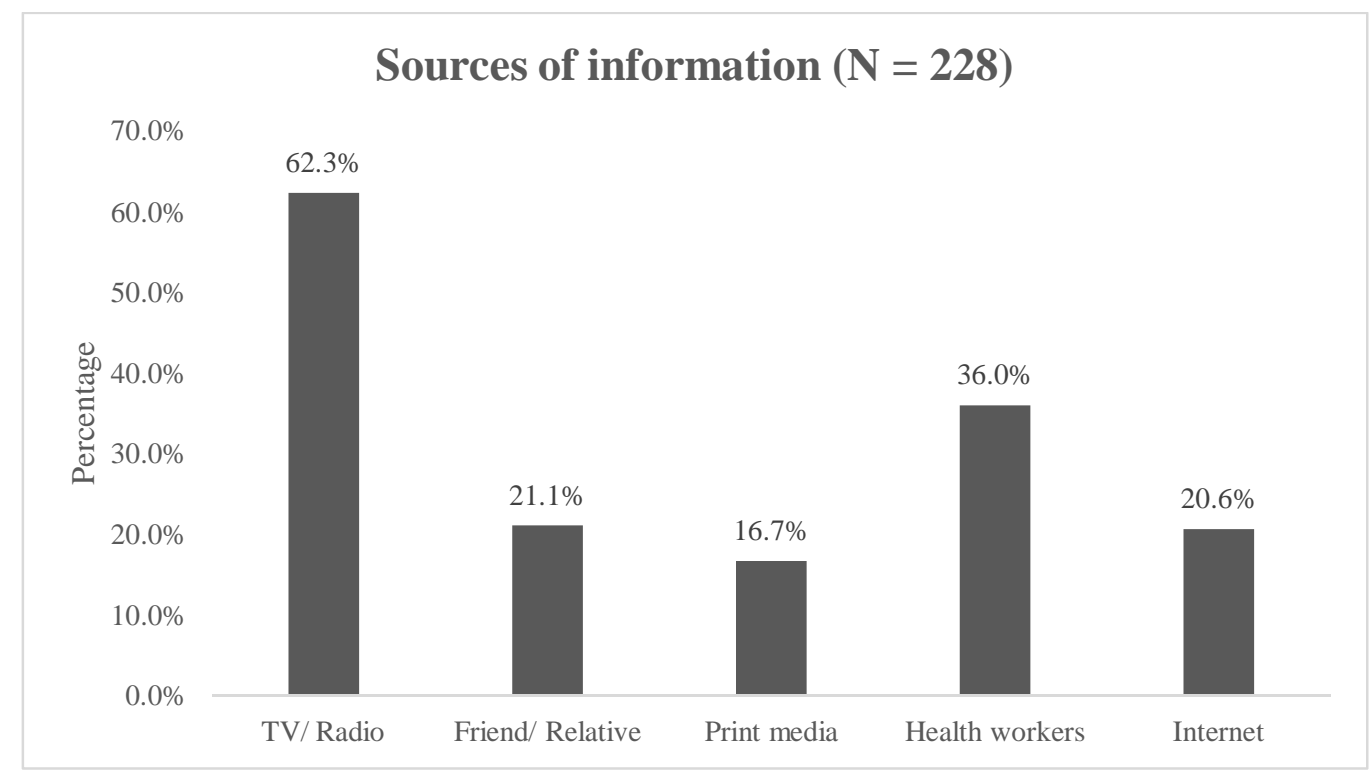

Figure 1: Respondents' sources of information about tobacco-related health information

More than three-fifths $(62.3 \%)$ of the respondents get health information on tobacco use from

TV/radio, and print media was found to be the least explored means of getting health

information. Also, amongst the respondents, $36 \%$ get health information from health workers while $21 \%$ and $20.6 \%$ get health information from friends /relatives and the internet, respectively. 


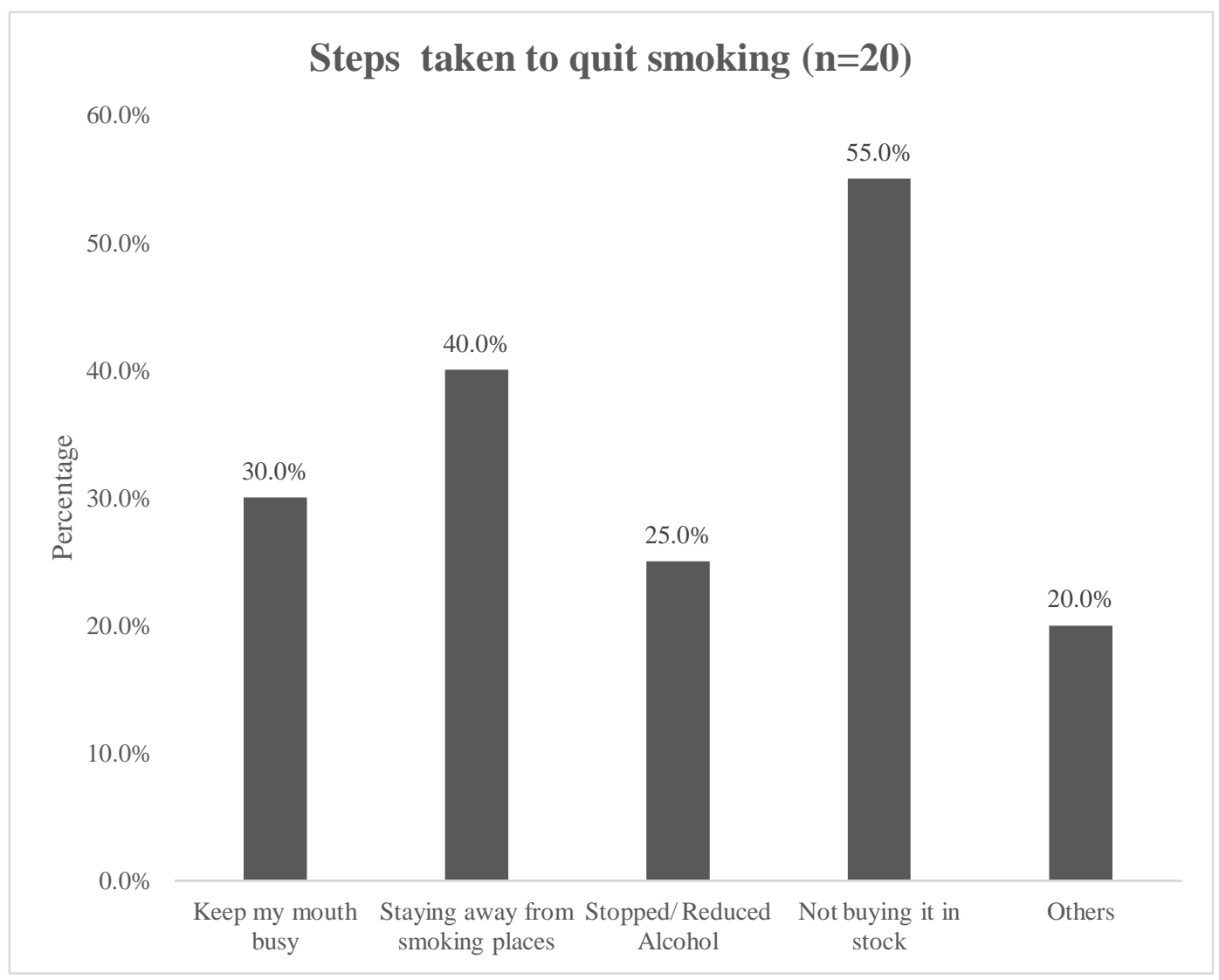

Figure 2: Steps were taken to quit smoking.

More than half (55\%) of the respondents tried quitting smoking by not buying cigarettes in stock, while a quarter (25\%) had attempted quitting by stopping the intake of alcohol. Another 30\% had attempted quitting by keeping their mouth busy with something else.

Furthermore, when asked about smoking restriction at the worksite, almost two-thirds of respondents (64.9\%) said there was no smoking restriction at work sites. 
medRxiv preprint doi: https://doi.org/10.1101/2021.04.08.21255137; this version posted April 11, 2021. The copyright holder for this preprint (which was not certified by peer review) is the author/funder, who has granted medRxiv a license to display the preprint in perpetuity.

It is made available under a CC-BY-NC-ND 4.0 International license .

\section{DISCUSSION}

In this study, the prevalence of ever used tobacco amongst CA was $19.3 \%$ and this was higher than the prevalence of ever smokers in the general population in Nigeria which was 3.9\%. ${ }^{9}$ Similarly, a survey analysis of national data between 1992 - 2007 in the United States also gave the prevalence of ever smokers among construction artisans in the United States to be $38 \%{ }^{11}$ and in Brazil, a cross-sectional survey among 418 male construction workers ever smoke prevalence was found to be $72.4 \% .{ }^{15}$ In these countries, the prevalence of ever used tobacco in the general population was $30 \%^{11,15}$ and $56.9 \%{ }^{15}$ in the United States and Brazil respectively. Therefore, the prevalence of ever used tobacco was particularly higher amongst this group of workers. However, the prevalence of ever smoke amongst CA in this study which was $19.3 \%$ is quite lower when compared to the prevalence of ever smoke amongst CA in Brazil which was $72.4 \% .{ }^{15}$ This may not be unconnected to the fact that the prevalence of smoking in the general population in Brazil $(56.9 \%)^{15}$ was far higher than the prevalence of ever smokers in the general population in Nigeria $(3.9 \%) .{ }^{3}$ It must also be stressed that the prevalence of ever smokers in the general population in Nigeria was low possibly because some adults for cultural, spiritual, and social reasons would not admit having ever used tobacco.

In this study, several factors were identified to be associated with smoking. The age of artisans, marital status, and marriage type of CA, whether or not CA were presently in school, years of experience, and level of expertise of the CA were found to be significantly associated with tobacco use amongst CA. Artisans who are within the age range 31-40 years were 4.4 times more likely to smoke than those $<20$ years. This was also in line with what Gavioli et al. (2014) found in a similar cross-sectional survey of 418 CA; CA who were more than 36 years of age have a high risk of tobacco use. Barbeau et al. (2004) and Okechechuwu 
medRxiv preprint doi: https://doi.org/10.1101/2021.04.08.21255137; this version posted April 11, 2021. The copyright holder for this preprint

et al. (2012) in their respective studies also highlighted a significant association between increasing age and smoking behavior among CA. ${ }^{16,17}$

Furthermore, CA who were divorced/separated were 4.2 times more likely to use tobacco. Liu et al. (2015) in a cross-sectional study amongst 5,380 migrants workers in China not only found 8.8 times increased risk of smoking in those who work in the construction sector but also found 2.2 times increased risk of smoking among these workers who were divorced. ${ }^{18}$ This could mean that physical stress of the construction work (which $31.8 \%$ of smokers admitted to) and smoking behavior of colleagues (which $86.4 \%$ of smokers admitted to) increases their uptake of smoking habit (Ajzen and Fishbein, 1980) on the one hand; and emotional and marital stress can increase their propensity to smoke on the other hand (Liu et al., 2015). ${ }^{13,18}$

Moreover, artisans with more than five years of work experience were more likely to be smoked when compared with those with lesser years of working experience. In this study, logistic regression analysis showed that CA with 6-10 years, 11-20 years, and > 20years of working experience were four times, five times, and six times respectively more likely to have ever smoker than those with less than one year experience. This was also in tandem with the findings of Gavioli et al. (2014) in a cross-sectional study of substance use amongst CA in Brazil $^{15}$. They opined that CA with more than 10 years of working experience had an increased risk of ever smoking tobacco. It can then be concluded that the longer an artisan stays on the job, the higher his chances of taking up a smoking habit. This could be because he would be more exposed to the stress and strain of the job which may demand the use of a substance such as tobacco to relieve. Moreover, the more years an artisan spends on his job, the larger his circle of friends who are his co-workers and who might also be a smoker. With time, he might also take up the smoking habit just to conform to his co-workers. 
It is also striking to note that almost two-thirds (64.9\%) of the respondents said there was no smoking restriction at the worksite. Asfar et al. (2018) also noted a lack of smoking intervention that is adapted to the work environment of Hispanics/ Latinos working in the construction industries in the United States. ${ }^{19}$ Unfortunately, this lack of smoking restrictions at worksites may serve as an impetus to continue smoking. The use of tobacco cessation interventions at the worksite has shown to impact significantly on the smoking habits of CA. ${ }^{10,19,20}$ A mixed-method intervention (focus group and survey data) used amongst members of the Carpenters' District Council in the United States showed that $65 \%$ of its 144 current smoking members were willing to quit smoking post-intervention. ${ }^{10}$ It was also noted that the majority responded positively to tailored messages and images on tobacco cessation.

\section{Limitations}

The information on tobacco use was self-reported and this might lead to reporting bias, but self-reported estimates of tobacco use from other studies have indicated that this kind of information is still valid (Syamlal et al., 2014). ${ }^{20}$ More so, triangulating this study with qualitative data on the perception of CA on smoking would have given additional information on the smoking behavior of CA.

\section{CONCLUSION}

This study assessed the prevalence of tobacco use amongst construction artisans in the communities in Ekiti State. It was found that the prevalence of cigarette smoking was higher amongst construction artisans than in the general population. Furthermore, the predisposing factors for the increased prevalence of this risky behavior amongst this group of workers were also assessed; age, marital status, and years of experience were strongly associated with indulgence in tobacco usage by CA. 
The impacts of indulging in this behavior span beyond the CA themselves. There are medical, social, economic, and public health implications of this behavior to their immediate families, communities, and society at large. Therefore, individuals, communities, and governments at all levels must strive to mitigate any social and health inequalities linked with this unhealthy behavior for a better and healthier society.

\section{DECLARATIONS}

\section{Ethics approval}

Research approval was obtained from the University of Liverpool ethics committee and the Ethics and Research Review Committee of the Federal Teaching Hospital, Ido Ekiti, Ekiti State, Nigeria.

\section{Consent for publication}

Not applicable

\section{Availability of data and materials}

The datasets used and/or analyzed during the current study are available from the corresponding author on reasonable request

\section{Competing interests}

The authors declare that they have no competing interests

\section{Funding}

No funding was received for this research 
medRxiv preprint doi: https://doi.org/10.1101/2021.04.08.21255137; this version posted April 11, 2021. The copyright holder for this preprint (which was not certified by peer review) is the author/funder, who has granted medRxiv a license to display the preprint in perpetuity.

It is made available under a CC-BY-NC-ND 4.0 International license.

\section{Authors`Contributions}

Conception/design of the study-COO, CMB, KAD; data collection- COO, ORO; data analysis and interpretation- $\mathrm{COO}, \mathrm{ORO}$; article drafting- $\mathrm{COO}, \mathrm{CMB}$; Critical revision of the article- $\mathrm{COO}, \mathrm{CMB}$, KAD; final approval of the version to be published-all authors

\section{Acknowledgment}

Commonwealth Scholarship Commission (CSC) for granting me a full scholarship to pursue my MPH degree at the University of Liverpool, United Kingdom, and supporting me throughout the time I was writing this dissertation. 
medRxiv preprint doi: https://doi.org/10.1101/2021.04.08.21255137; this version posted April 11, 2021. The copyright holder for this preprint (which was not certified by peer review) is the author/funder, who has granted medRxiv a license to display the preprint in perpetuity.

It is made available under a CC-BY-NC-ND 4.0 International license .

\section{References}

1. Ogunsemi DR, Jagboro GO. Time-cost model for building projects in Nigeria. Constr Manag Econ. 2006 Mar [cited 2021 Mar 15];24(3):253-8. Available from: https://www.tandfonline.com/doi/abs/10.1080/01446190500521041

2. $\quad$ Sunday Julius Odediran B, Babalola O, Julius Odediran $\alpha$ S, Babalola $\sigma$ O. Employment Structure of Informal Construction Workers/Artisans in Nigeria. Glob J Manag Bus Res Adm Manag. 2013 [cited 2021 Mar 15];13(11). Available from: https://journalofbusiness.org/index.php/GJMBR/article/view/1129

3. Wahab AB. Stress Management among Artisans in Construction Industry in Nigeria. Glob J Res Eng. 2010;10(1):93-103.

4. Mooko N, Aina LO. Information environment of artisans in Botswana. Vol. 57, Libri. Walter de Gruyter GmbH \& Co. KG; 2007 [cited 2021 Mar 15]. p. 27-33. Available from: https://www.degruyter.com/document/doi/10.1515/LIBR.2007.27/html

5. Ekpo K, Okon A. Vocational Education and Economic Development in Nigeria. Afrrev Ijah An Int J Arts Humanit. 2014 Jun 17 [cited 2021 Mar 15];3(2):322. Available from: https://www.ajol.info/index.php/ijah/article/view/104325

6. World Health Organization. Building Blocks for Tobacco Control, a Handbook. Geneva; World Health Organization. 2004 [cited 2021 Mar 15]. p. 4-13. Available from:

https://apps.who.int/iris/bitstream/handle/10665/42993/9241546581_eng.pdf;jsessioni $\mathrm{d}=7 \mathrm{C} 2 \mathrm{E} 554 \mathrm{~A} 9 \mathrm{~F} 458013 \mathrm{C} 78833 \mathrm{EAB} 98 \mathrm{C} 42 \mathrm{FD}$ ?sequence $=1$

7. Townsend L, Flisher AJ, Gilreath T, King G. A Systematic Literature Review of Tobacco use among Adults 15 years and older in sub-Saharan Africa. Vol. 84, Drug and Alcohol Dependence. Elsevier; 2006. p. 14-27.

8. Nations U. Transforming Our World: The 2030 Agenda for Sustainable Development. In: A New Era in Global Health. 2018.

9. World Health Organisation. Report on the Global Tobacco Epidemic, 2013. ASHEERIC High Educ Rep. 1994 [cited 2021 Mar 15];23(7):iii-vii. Available from: https://www.who.int/tobacco/mpower/2009/gtcr_download/en/

10. Strickland JR, Smock N, Casey C, Poor T, Kreuter MW, Evanoff BA. Development of targeted messages to promote smoking cessation among construction trade workers. Health Educ Res. 2015 Feb 1 [cited 2021 Mar 15];30(1):107-20. Available from: /pmc/articles/PMC4296889/

11. Ham DC, Przybeck T, Strickland JR, Luke DA, Bierut LJ, Evanoff BA. Occupation and workplace policies predict smoking behaviors: Analysis of national data from the current population survey. J Occup Environ Med. 2011 [cited 2021 Mar 15];53(11):1337-45. Available from:/pmc/articles/PMC3217081/

12. Mlinga RS, Wells J. Collaboration between formal and informal enterprises in the construction sector in Tanzania. Habitat Int. 2002;26(2):269-80.

13. Ajzen I, Fishbein M. Understanding attitudes and predicting social behaviour. Prentice Hall. 1980 [cited 2021 Mar 15]. Available from:

https://www.scirp.org/(S(351jmbntvnsjt1aadkposzje))/reference/ReferencesPapers.asp 
medRxiv preprint doi: https://doi.org/10.1101/2021.04.08.21255137; this version posted April 11, 2021. The copyright holder for this preprint

(which was not certified by peer review) is the author/funder, who has granted medRxiv a license to display the preprint in perpetuity.

It is made available under a CC-BY-NC-ND 4.0 International license .

$\mathrm{x}$ ?ReferenceID $=1779558$

14. Jekel's Epidemiology, Biostatistics, Preventive Medicine, and Public Health, 4th Edition. Vol. 46, Medicine \& Science in Sports \& Exercise. 2014 [cited 2021 Mar 15]. 2191 p. Available from: https://www.elsevier.com/books/jekels-epidemiologybiostatistics-preventive-medicine-and-public-health/katz/978-1-4557-0658-7

15. Gavioli A, De Freitas Mathias TA, Rossi RM, De Oliveira MLF. Risco relacionado ao consumo de drogas em homens trabalhadores da construção civil. ACTA Paul Enferm. 2014 [cited 2021 Mar 15];27(5):471-8. Available from: https://www.scielo.br/scielo.php?script=sci_arttext\&pid=S0103-21002014000500013

16. Barbeau EM, Krieger N, Soobader MJ. Working Class Matters: Socioeconomic Disadvantage, Race/Ethnicity, Gender, and Smoking in NHIS 2000. Am J Public Health. 2004 Feb 10 [cited 2021 Mar 15];94(2):269-78. Available from: http://ajph.aphapublications.org/doi/10.2105/AJPH.94.2.269

17. Okechukwu C, Bacic J, Cheng KW, Catalano R. Smoking among construction workers: The nonlinear influence of the economy, cigarette prices, and antismoking sentiment. Soc Sci Med. 2012 Oct [cited 2021 Mar 15];75(8):1379-86. Available from: /pmc/articles/PMC3510701/

18. Liu Y, Song H, Wang T, Wang T, Yang H, Gong J, et al. Determinants of tobacco smoking among rural-to-urban migrant workers: A cross-sectional survey in Shanghai. BMC Public Health. 2015 Dec 12 [cited 2021 Mar 15];15(1):131. Available from: http://bmcpublichealth.biomedcentral.com/articles/10.1186/s12889-015-1361-X

19. Asfar T, Caban-Martinez AJ, McClure LA, Ruano-Herreria EC, Sierra D, Gilford Clark G, et al. A cluster randomized pilot trial of a tailored worksite smoking cessation intervention targeting Hispanic/Latino construction workers: Intervention development and research design. Contemp Clin Trials. 2018 Apr 1 [cited 2021 Mar 15];67:47-55. Available from: /pmc/articles/PMC6377564/

20. Syamlal G, King BA, Mazurek JM. Tobacco product use among workers in the construction industry, United States, 2014-2016. Am J Ind Med. 2018 Nov 1 [cited 2021 Mar 15];61(11):939-51. Available from: /pmc/articles/PMC6350769/ 